\title{
Cytotoxic and inhibitory activity of ceramide on cancer cell lines
}

\author{
Muthana Ibrahim Maleek
}

Department of Biology, College of Science, University of Baghdad, Baghdad, Iraq. Email: fadhilsalih@gmail.com

Received 21 January 2010; revised 15 February 2010; accepted 15 February 2010.

\begin{abstract}
The inhibitory activity of ceramide on cancer cells was evaluated and its cytotoxicity on different cancer cell lines was measured. Ceramide was separated fro$m$ bovine brain and spinal cord, and extracted by organic solvents. The crude extract was purified by using silicic acid column. Detection and identification of purified extract were carried out by using three assays: visualization, spectrophotometry and infrared. Cytotoxic effect of different concentrations $(7,15,30$ and $60 \mu \mathrm{M})$ of ceramide on HEp-2, RD , AMGM5, REFAM3 and AMN3 cancer cell lines was studied. Results showed that ceramide at $30 \mu \mathrm{M}$ imposed cytotoxic activity on all cancer cell lines especially on AMGM5. Effect of ceramide at $30 \mu \mathrm{M}$ on cell division of human lymphocyte was also examined. Significant reductions in mitotic and blast indices were observed. In addition, No genotoxic effects or chromosomal aberration were detected in lymphocyte chromosomes when ceramide was tested in vitro.
\end{abstract}

Keywords: Ceramide; Cancer Cell Line; Cytotoxicity; Genotoxicity; Chromosomal Aberration

\section{INTRODUCTION}

Cancer is a clonal disorder characterized by genetic instability and shift in the control mechanism that govern cell proliferation and differentiation [1,2]. It is a worldwide health problem, with a geographical variation all over the world [3].

Conventional cancer therapy is based on surgery, radiotherapy, chemotherapy or combinations of them. Generally, surgery and radiotherapy are preferred in localized tumors and chemotherapy is used when cancer cells are spread through the body [4]. The introduction of cancer chemotherapy in the 5th and 6th decades of the last century has resulted in the development of curative therapeutic interventions for patients with several types of solid tumors and hematopoietic neoplasms. However, important obstacles were encountered in the use of chemotherapy that included toxicity to the normal tissues of the body and the presence of mutations that confer resistance to these chemotherapeutic agents [5]. Therefore, cancer patients as well as many physicians began to request natural products for treatment due to their multiple effects in treating the disease, relieving patient's symptoms in addition to improved safety and lower cost [6]. Natural products have long been a fertile source of cure for cancer, which is projected to become the major cause of death in this century [7]. Therefore, a natural product, ceramide, was tested for its inhibitory and cytotoxic effects on tumor cells.

The combination of sphingosine plus fatty acid is known as ceramide (n-acylsphingosine), sphingosine or related bases are important membrane components in animal cells. They are present in large amounts especially in brain and nerve tissue. Sphingolipids can be found in all eukaryotic cells and the major phosphosphingolipid, sphingomyelin, is very abundant in the outer leaflet of the plasma membrane constituting of about $30 \%$ of all lipids [8]. However, altogether over 300 sphingolipids with distinct head groups have been identified in eukaryotic cells. In most mammalian cells, the structure is based on the long chain of sphingosine base, which is subsequenttly acylated to form ceramide (Figure 1) and more complex sphingolipids are formed by the addition of polar head groups to the $\mathrm{C} 1$ position of ceramide [9]. Sphingomyelins as phospholipids are formed when ceramide reacts with phosphatidylcholine to form sphingomyelin plus diacylglycerol. This occurs mainly in the Golgi apparatus and to a lesser extent in the plasma membrane. In organelles involved in secretory and endocytic processes sphingomyeline is restricted to the luminal aspect [10].

Ceramide was confirmed to function as a second messenger in several cellular processes, including apoptosis, growth suppression, differentiation, transformation, proliferation, regulate cell-cell, cell-substrate interactions and 


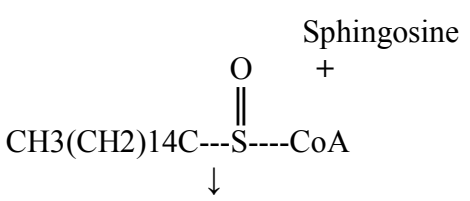

Palmitoyl-CoA

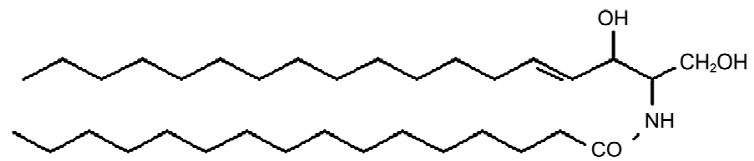

Ceramide (N-palmitoylsphingosine)

Figure 1. Formation of ceramide [10].

cell senescence [11]. In turn, aberrant metabolism of ceramide has been associated with inflammation, tumori genesis, diabetes, and neurodegenerative disorders $[12,13]$. Ceramide has emerged as a novel class of signaling molecules that also regulate phagocytosis [14]. The aim of this study is to purify and characterize the ceramide that was isolated from bovine brains and to study its ability to inhibit tumor cells in vitro.

\section{MATERIALS AND METHODS}

\subsection{Chemicals and Culture Media}

Ciramide was separated and purified according to Dasgupa et al. [15] and Dasgupta and Hogan, [16]. A modified method of Bischel and Austin [17] was used to visualize ceramide. The modification offered more sensitive and stable color reaction in practice (down to $5-10 \mu \mathrm{g}$ ).

Silica gel G thin-layer chromatography and standard solvent systems (chloroform: methanol: acetic acid; 95: 4.5:0.5) were employed to visualize ceramide. Chromatograms were dried in a ventilated hood and sprayed with the clorox reagent $(5 \mathrm{ml}$ of clorox was added to $50 \mathrm{ml}$ benzene and then $5 \mathrm{ml}$ glacial acetic acid). The clorox reagent must be used immediately. After spraying, chromatograms were air dried in a hood to remove all unbound $\mathrm{Cl}_{2}$. In addition, paper chromatograms were also used for ceramide visulization. They were rinsed twice with tap water for 1-2 min duration, and allowed to air dry until damp. They were then sprayed with benzidine reagent $(0.5 \mathrm{~g}$ benzidine and $0.2 \mathrm{~g}$ of KI dissolved in $50 \mathrm{ml}$ of $50 \%$ ethanol) and then filtered. This solution was kept out of direct light and used within $2 \mathrm{~h}$ after preparation. Alternatively, paper chromatograms may be dipped in the benzidine reagent. Two more ways were also used for visualization purposes; spectrophotometry assay and Infrared assay, as described by Mc Murry [18].

Rosswell Park Memorial Institute (RPMI)-1640 medium [19] was used as cell line growth medium. It was kindly provided by ICCMGR. All chemicals, solvents and reagents were supplied by BDH (UK) unless otherwise stated.

\subsection{Cell Lines}

1) Human larynx epidermoid carcinoma (HEp-2) cell line was kindly provided by the Iraqi Center for Cancer and Medical Genetics Research (ICCMGR). This human cell line was originally obtained from a 57-year-old man with a primary tumor of the larynx. Its biological and chemical sensitivity has been very well documented [20-23].

2) Rhabdomyosarcoma (RD) cell line was kindly provided by ICCMGR. This human cell line was derived from a biopsy specimen obtained from a pelvic rhabdomyosarcoma of a 7-year-old

3) Ahmed-Majeed-glioblastoma-multiforme-2005 (AMGM5) cell line was kindly provided by Dr. A. Al-Shamery from ICCMGR. This human cell line was obtained from a human cerebral glioblastoma multiforme (GBM) of a 72-year-old Iraqi male who underwent surgery for intracranial tumor. Morphologic examination, immunocytochemical staining, growth kinetics, and karyotypic characteristics of this cell line were studied at ICCMGR [A. Al-Shamery, personal communication]. The cultured cells were spindle-like or polyhedral in shape. The population doubling time was 28 hours. The chromosomal number varied between 38 and 46, with mode chromosomal number of 42 . In addition, chemotherapeutic drug sensitivity was studied for AMGM5 cells at ICCMGR and the cells appeared to be resistant to Cisplatin, Vincristine and Etoposide.

4) Ahmed-Mohammed-Nahi-2003 (AMN3) cell line was kindly provided by ICCMGR. This murine mammary adenocarcinoma cell line was derived from a spontaneous mammary adenocarcinoma of female BALB/c mice [25].

5) Rat Embryo fibroblasts (REFAM3) cell line was established and kindly provided by Dr. A. Al-Shamery from ICCMGR. Cells of this normal murine cell line were a mixture of fibroblastic and epithelial cells with normal chromosomal picture [25].

Cell lines were maintained as described by Freshney [19].

\subsection{Assay of Ceramide Toxicity}

Confluent monolayers were treated as in subculture .The growth medium was decanted off and the cell sheet washed twice with PBS and trypsinized using trypsin-versene (Gibco, Canada) [19]. When the cells are in exponential growth, medium was removed and ceramide at varying concentrations $(7,15,30$ and $60 \mu \mathrm{M})$ in serum free medium (SFM) plus DMSO $(1 \mu \mathrm{l} / \mathrm{ml})$ [26] were added to the wells, five replicates were used for each concentration of ceramide. Twenty columns were used as control (cells treated with SFM plus DMSO only). Plates were 
re-incubated at $37^{\circ} \mathrm{C}$ for $24 \mathrm{hrs}$ and then medium was replaced by $50 \mu 1$ of $0.01 \%$ crystal violet dye for $20 \mathrm{~min}$ utes, washed gently and allowed to dry [19]. Optical density of each well was read by using a micro-ELISA reader (Organon Teknika, Austria) at $492 \mathrm{~nm}$ transmitting wavelength $[19,27]$. The percentage of inhibition was calculated according to the following formula [28].

$$
\begin{aligned}
& \text { Inhibition }(\%) \\
& =\left(100-\frac{\text { optical density of test wells }}{\text { optical density of control wells }}\right) \times 100
\end{aligned}
$$

\section{RESULTS AND DISCUSSION}

Ceramide was separated from bovine brain and spinal cord. The detection and identification of purified extract were examined by using different assays. Using the benzidine spray visualization assay ceramide was detected by the virtue of the reaction of their secondary amide group belongs to the test compound with CL-substituted. After that the result of combination with benzidine spray was observed, blue product was formed, which means that the extract was sphingolipid, as illustrated by Bischel and Austin [17]. Since ceramide is one of the sphingolipid classes [10] additional assays were carried out to characterize it. A purified fraction which extracted by silicic acid was examined by spectrophotometer at a wide ranges of wavelength (between 200-1100 nm). One peak at wavelength $326 \mathrm{~nm}$ with absorbance 1.481 was noticed (Figure 2). Examination of the purified compound by infrared instrument showed many peaks for many infrared absorption frequencies (Figure 3 ) and each value of absorption was referred to a functional group of test compound as follow: [748.34 (O-disubstituted), 964.34 $(\mathrm{RCH}=\mathrm{CH} 2), 1126.35(-\mathrm{C}-\mathrm{C}$-), 1280.65 (-O-C-ether), 1380.94-1458.8(CH2), 1650(C = C), $1728.10(\mathrm{C}=\mathrm{O})$, 2854.45(C-H strong), 2923.88(C-H alkane), 2970$3140(\mathrm{~N}-\mathrm{H})$ and $3363.62(-\mathrm{O}-\mathrm{H}$ alcohol)]. When these functional groups were compared with the chemical components of ceramide, the results showed that the extracted compound can be identified as ceramide according to Mc Murry [18].

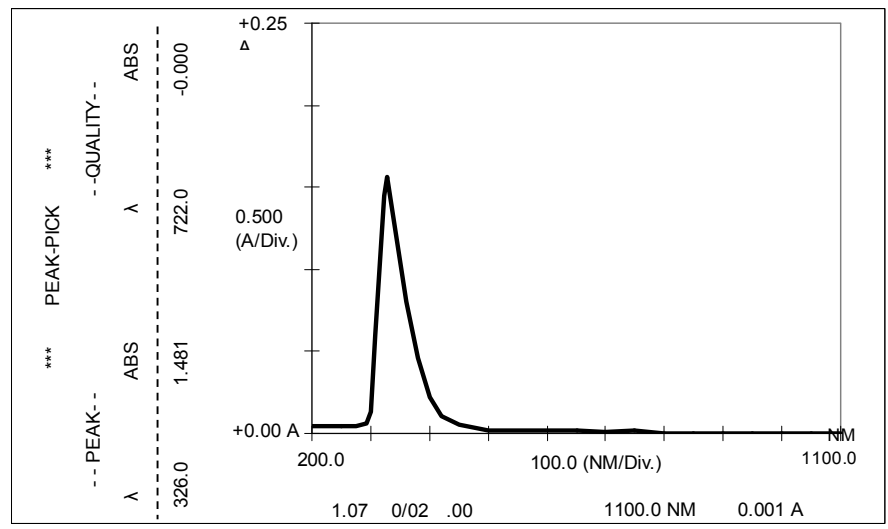

Figure 2. Spectrogram of extracted ceramide.

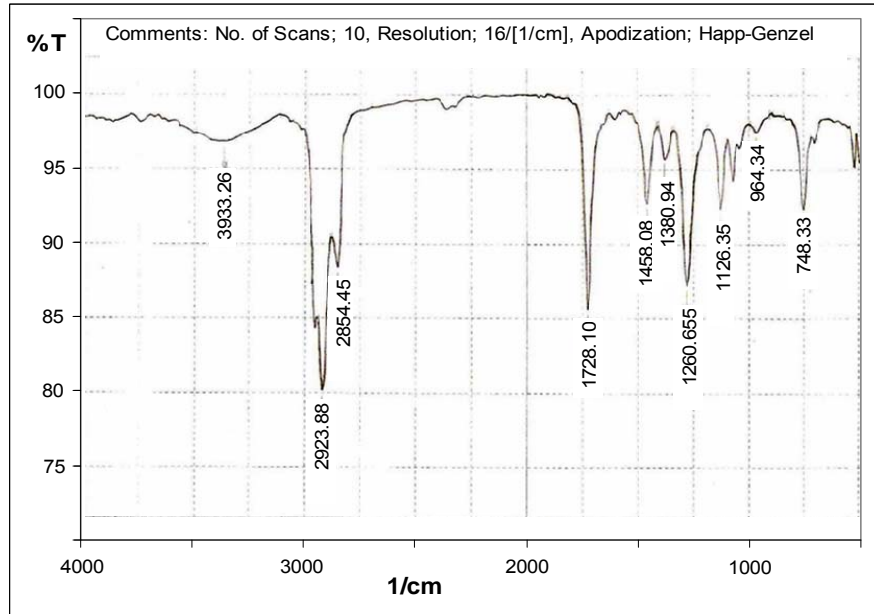

Figure 3. Infrared absorption frequencies assay for ceramide extract. 
Effect of different concentrations of purified ceramide on HEp-2 cells was studied (Figure 4). There was a reduction in cell viability in almost all tested concentrations of ceramide. The percentage of inhibition was $13.2 \%$ at $15 \mu \mathrm{M}$ of ceramide. Similarly a percentage of inhibition of $13.1 \%$ was obtained when cells treated with $30 \mu \mathrm{M}$ of ceramide. But when the highest ceramide (60 $\mu \mathrm{M})$ a percentage of inhibition of $12.5 \%$ was obtained. However, $7 \mu \mathrm{M}$ of ceramide imposed the lowest cyto- toxic efficacy on HEp-2 cells, where the percentage of inhibition was $1 \%$.

Different concentrations of ceramide influenced the viability of RD cells as shown in Figure 5. Low concentrations of ceramide ( 7 and $15 \mu \mathrm{M}$ ) showed low toxic effect on the viability of RD cells, giving percentage of inhibition of $6.7 \%$ and $7.5 \%$, respectively. However, $30 \mu \mathrm{M}$ of ceramide produced higher toxic effect of $26.3 \%$, followed by a reduction to $18.8 \%$ at $60 \mu \mathrm{M}$.

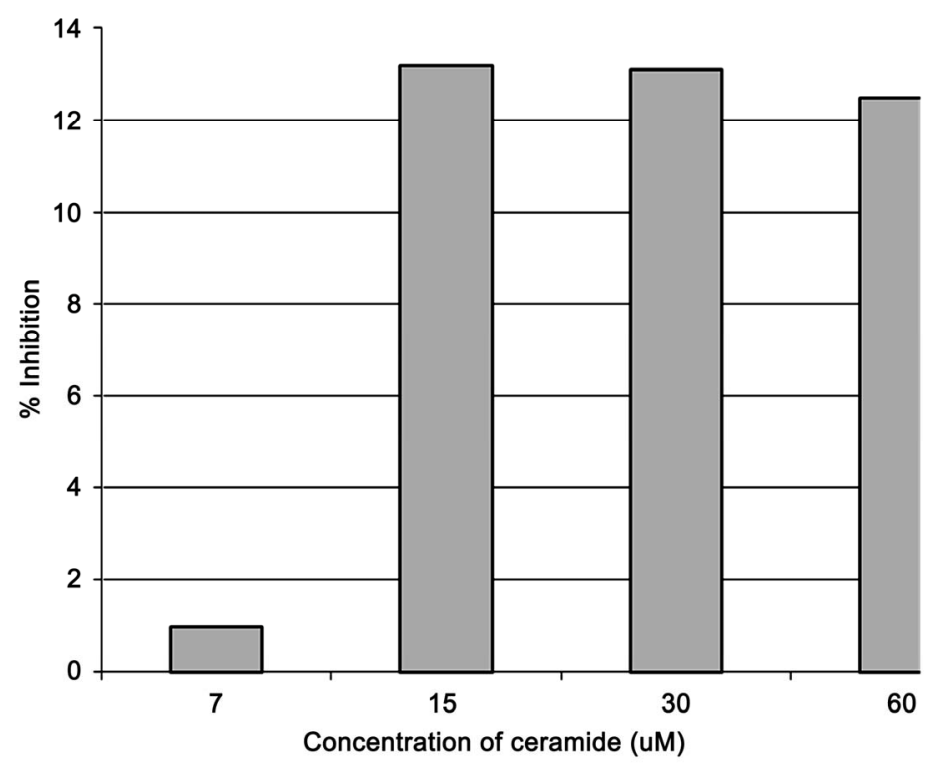

Figure 4. Effect of different concentration of ceramide on viability of HEp-2 cell line $(\mathrm{P} \leq 0.05)$.

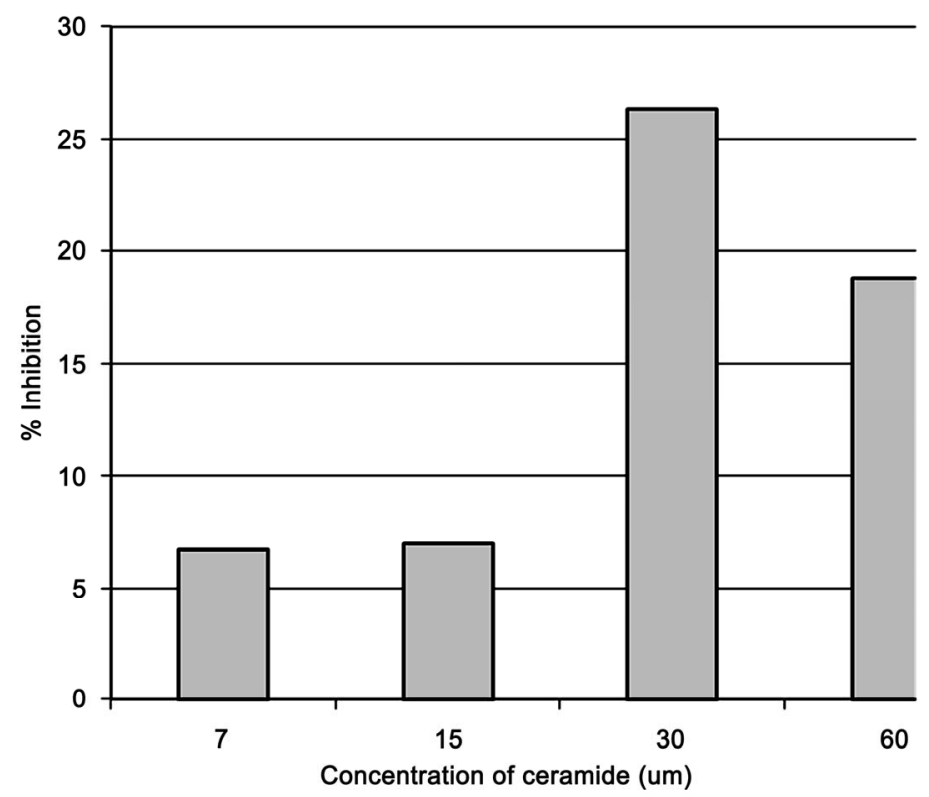

Figure 5. Effect of different concentration of ceramide on viability of $\mathrm{RD}$ cell line $(\mathrm{P} \leq 0.05)$. 
AMGM5 cells underwent significant toxic changes towards different concentrations of ceramide (Figure 6). The percentage of AMGM5 cells inhibition was gradually increased (21, 47 and 79\%) when treated with 7, 15 and $30 \mu \mathrm{M}$ of ceramide, respectively. At $60 \mu \mathrm{M}$ of ceramide the percentage of inhibition decreased to (50\%). It is apparent that AMGM5 cells treated with $30 \mu \mathrm{M}$ of ceramide showed suffered a significant reduction in cells viability.

The cytotoxic effect of different concentration of ceramide on viability of AMN3 cells were illustrated in Figure 6. The percentage of inhibition was gradually increased $(3.06,10.7,13.26$ and $19.13 \%)$ at concentrations of the ceramide $7,15,30$ and $60 \mu \mathrm{M}$, respectively.
The cytotoxicity effects of different concentrations of ceramide on normal cells line REFAM3 were illustrated in Figure 7. Both concentrations of ceramide 30 and 60 $\mu \mathrm{M}$ achieved high percentage of inhibition of 16.7 and $15.5 \%$, respectively. While cells treated with low concentrations of ceramide ( 7 and $15 \mu \mathrm{M}$ ) showed low level of toxicity giving percentage of inhibition of 11.3 and $3.3 \%$, respectively.

According to the above findings, it can be concluded that ceramide has inhibitory activity on almost all cell lines used in this study. As shown in Figure 8 that ceramide at $30 \mu \mathrm{M}$ has a clear cytotoxic activity on all cell lines used, especially on AMGM5 cells; the mean of growth inhibition was 49.4\% (Figure 9). This may be

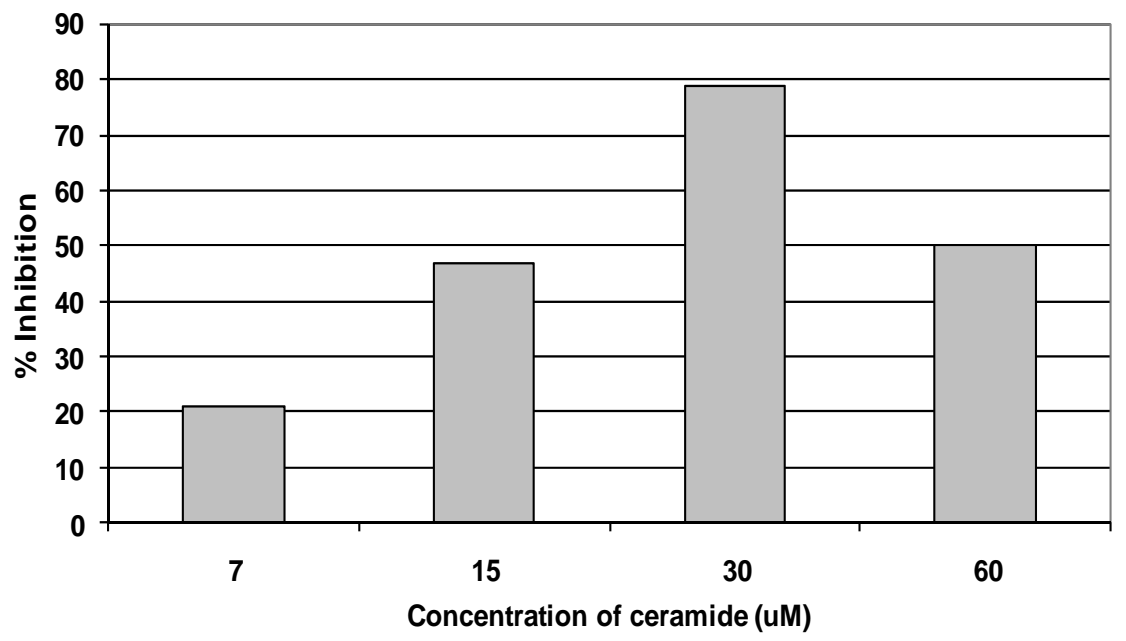

Figure 6. Effect of different concentration of ceramide on viability of AMGM5 cells $(\mathrm{P} \leq 0.05)$.

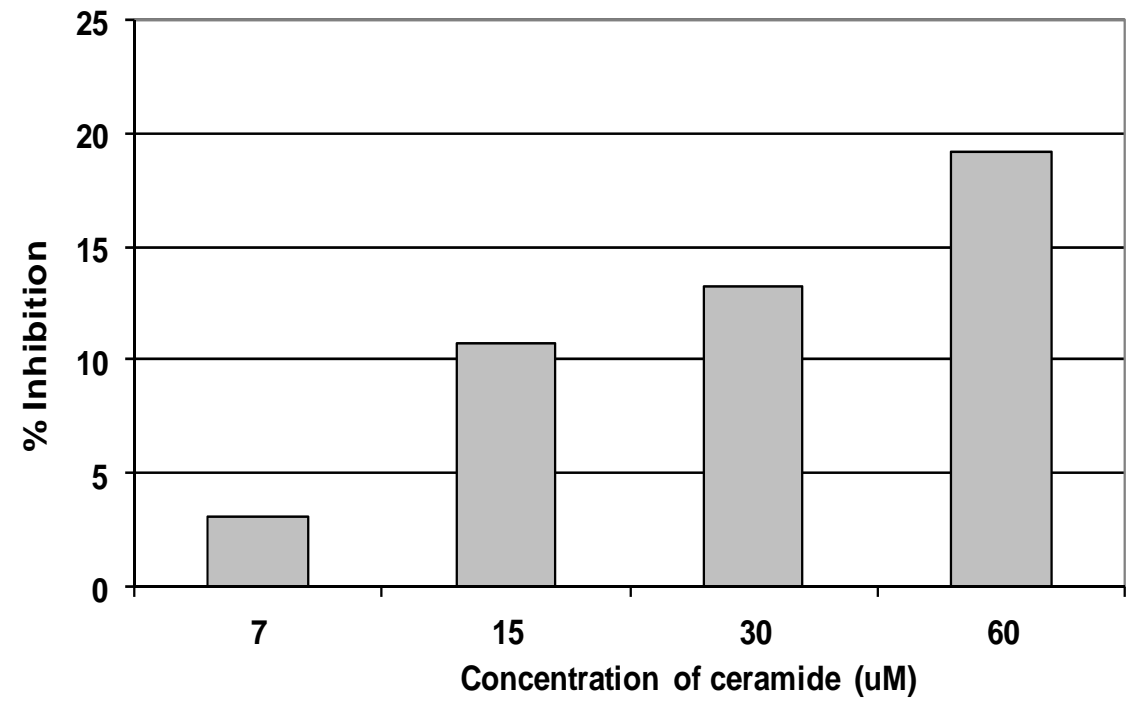

Figure 7. Effect of ceramide on viability of AMN3 cells $(\mathrm{P} \leq 0.05)$. 


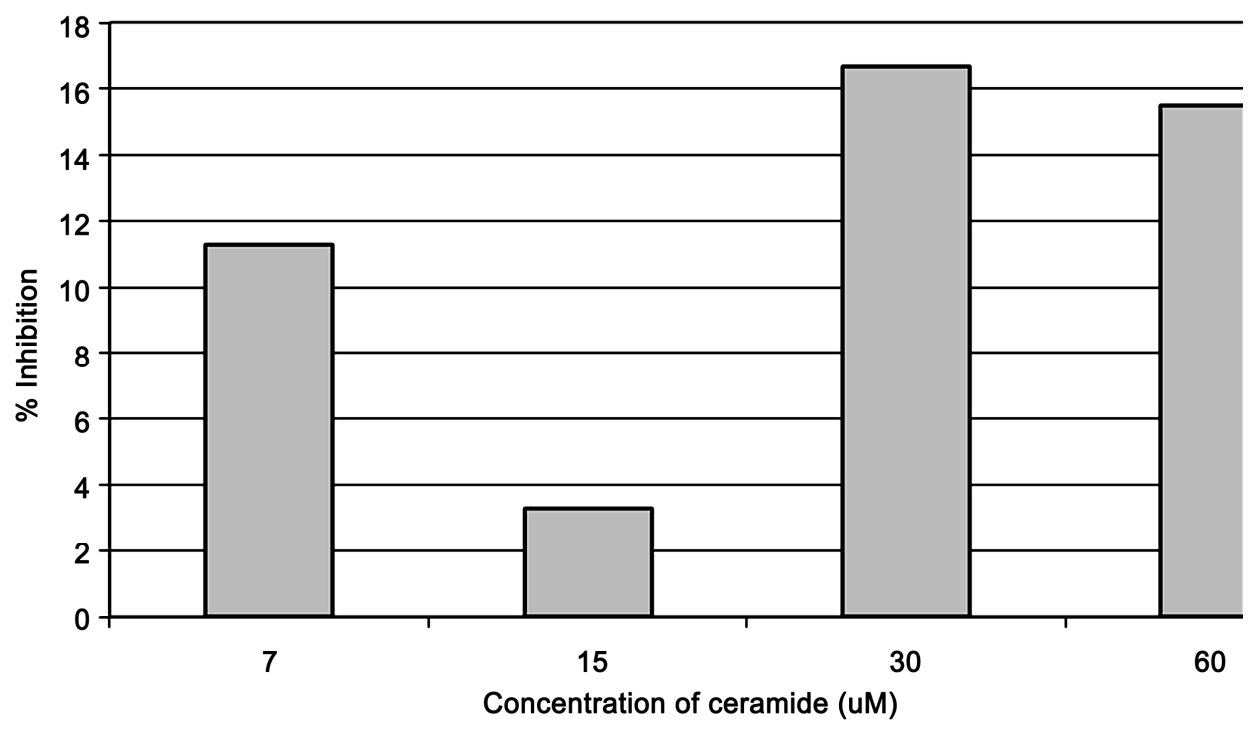

Figure 8. Effect of different concentration of ceramide on viability of REFAM3 cells $(\mathrm{P} \leq 0.05)$.

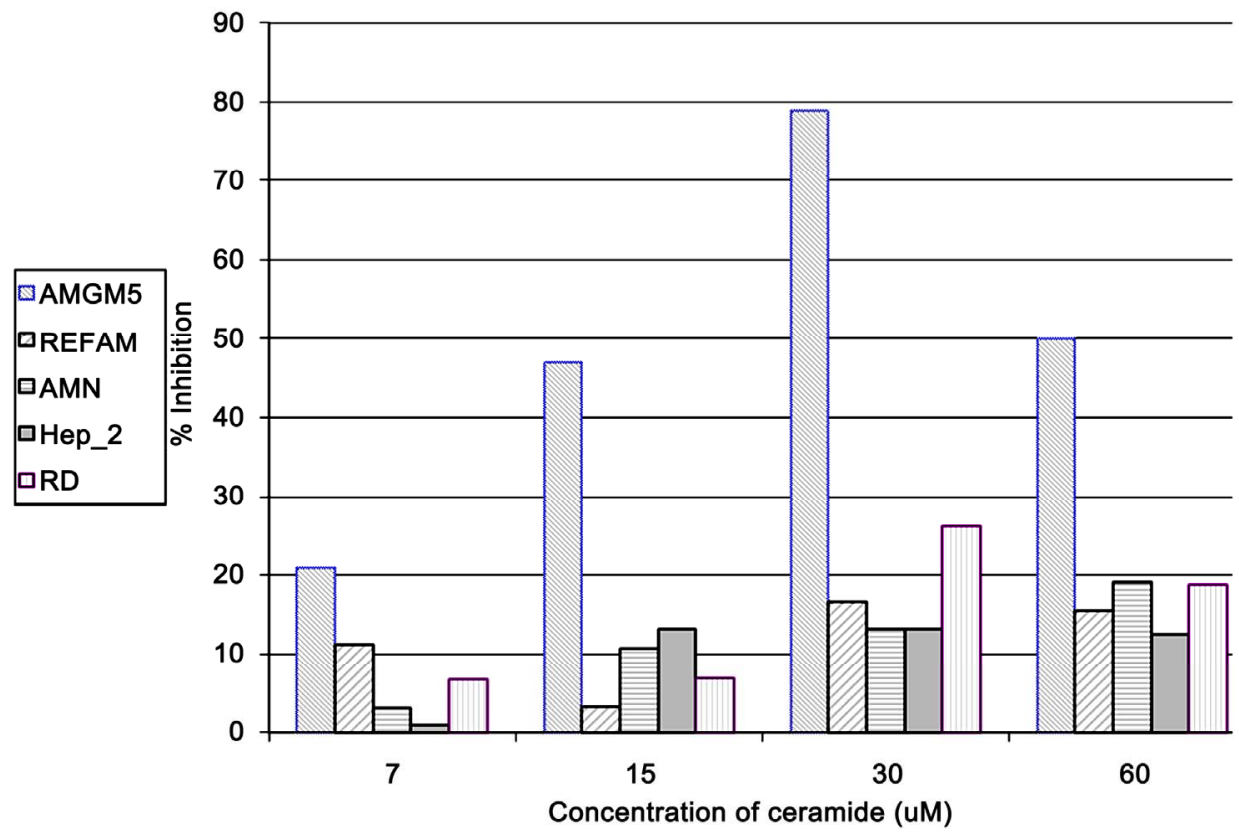

Figure 9. Relationship between growth inhibition of cell lines at different concentrations of ceramide $(\mathrm{P} \leq 0.05)$.

due to the cellular nature of AMGM5 cell line. As mentioned earlier that AMGM5 is a human cell line originated from a human cerebral glastoblastoma multiforme (GBM). In addition, ceramide was proved to bind vigorously to CD95 receptors on cerebral cells, thus this specificity of engagement may initiate multiple signaling pathways that lead to activate caspases which is responsible for apoptosis [29-31]. This conclusion agreed with that of Seumois et al. [32] who recently demonstrated on the de novo generation that ceramide contributes to spo- ntaneous neutrophil apoptosis via caspase activation. On the other hand, the addition of ceramide to REFAM3, a normal cell line which is a mixture of fibroblastic and epithelial cells with normal chromosomal picture, showed low cytotoxic effect of ceramide (Figure 9 and 10). This may be attributed to the ability of these cells to generate ceramide-1-phosphate (cer-1-p) by the action of ceramide kinase [33]. Subsequently, cer-1-p in plasma membrane can be hydrolyzed by phosphatases [34]. Recently, Rile et al. [35] reported that cer-1-p can also be 


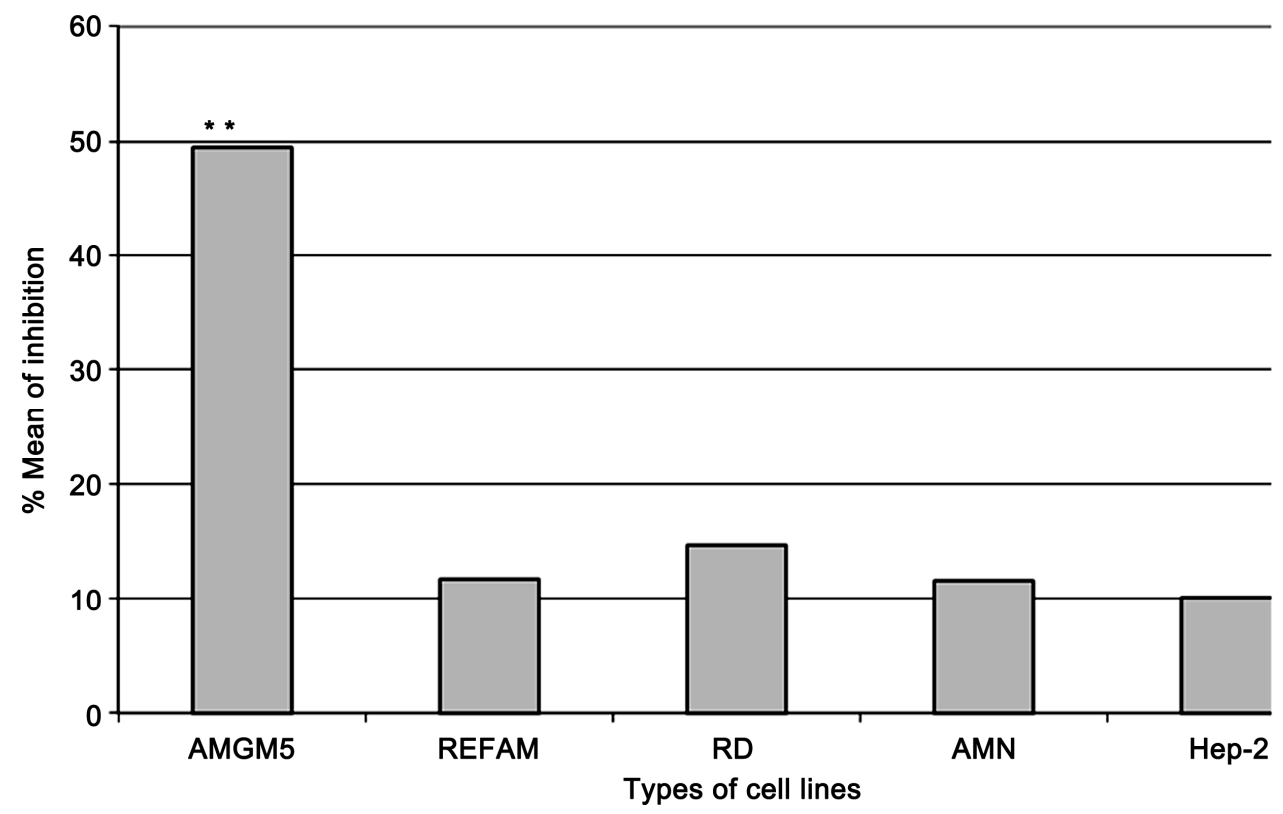

Figure 10. Mean of growth inhibition of five cell lines after treated with ceramide $(\mathrm{P} \leq 0.01)$.

formed intracellularly.

It can be concluded that ceramide has cytotoxic properties on cancer cell while it is much less toxic to normal cells. Generally, $30 \mu \mathrm{M}$ of this compound gave the highest affect in almost all cancer cell lines tested.

\section{REFERENCES}

[1] Knudson, A.G. (1985). Hereditary cancer oncogenes and antioncogenes. Cancer Research. 45(4), 1437 1443 .

[2] Katzung, B.G. (2001). Basic and clinical pharmacology. 8th (ed). International Edition. Long Medical Books, McGraw-Hill. New York.

[3] Brown, H.; Goble, R. and Kirschner, H. (1995). Environmental helth perspect. 103, 64-70.

[4] Lopez-Lazaro, M. (2002). Flavonoids as anticancer agents: Structure-Activity elationship study. Current. Medicinal Chemistry-Anti-Cancer Agents, 2(6), 691714.

[5] DeVita, V.T., Hellmany, S. and Rosenberg, S.A. (1997). Cancer: Principles \& practice of oncology. 5th Edition, Lippincott-Raven Publishers, Phiadelphia.

[6] Katz, A.E. (2002) Flavonoid and botanical approaches to prostate health. The Journal of Alternative and $\mathrm{Co}$ mplementary Medicine, 8(6), 813-821.

[7] Mukherjee, A.K., Basu, S., Sarkar, N. and Ghosh, A.C. (2001) Advances in cancer therapy with plant based natural products. Current Medicinal Chemistry, 8, 1467 1486.

[8] Rothman, J.E. and Lenard. J. (1977) Membrane asymmetry. Science, 195(4280), 743-753.

[9] Huwiler, A., Kolter, T., Pfeilschifter, J. and Sandhoff, K. (2000) Physiology and pathophysiology of sphingolipid metabolism and signaling. Biochim Biophys.
Acta. 14(85), 63-99.

[10] Lehninger, A.L. (2006) Biochemistry.6th Edition, Worth Publishers, Inc., New York.

[11] Coll, O., Morales, A., José, C., Checa, F. and Carmen Garcia-Ruiz, C. (2007) Neutral sphingomyelinase-induced ceramide triggers germinal vesicle breakdown and oxidant-dependent apoptosis in Xenopus laevis oocytes. Journal of Llipid Research, 48(9), 1924-1935.

[12] Litvak, D.A., Bilchik, A.J. and Cabot, M.C. (2003) Modulators of ceramide metabolism sensitize colorectal cancer cells to chemotherapy: a novel treatment strategy. Journal of Gastrointestinal Surgery, 7(1), 140148.

[13] Buccoliero, R. and Futerman, A.H. (2003) The roles of ceramide and complex sphingolipids in neuronal cell function. Pharmacological Research, 47(5), 409-419.

[14] Galcheva, V., Boxer,L., Kindzelskii, A., Hiraoka, M., Abe, A., Goparju, S., Spiegel, S., Howard R. and Shayman, J.(2005) Ceramide 1-phosphate, a mediator of phagocytosis. Journal of Biological Chemistry, 280 (28), 26612-26621.

[15] Dasgupta, S. and Hogan, E.L. (2001) Chromatographic resolution and quantitative assay of CNS tissue sphingoids and sphingolipids. Journal of Lipid Research, 42, 301-308.

[16] Dasgupta, S., Glushka, J., Van Halbeek, H., and Hogan, E.L. (1994) Branched monosialo gangliosides of the lacto-series isolated from bovine erythrocytes: characterization of a novel ganglioside, Neu Gc-iso Octaosylceramide. Archives of Biochemistry and Biophysics, 310, 373-384.

[17] Bischel, M.D., and Austin, J.H. (1963) A modified benzidine method for the chromatographic detection of sphingolipids and acid polysaccharides. Biochimica et Biophysica Acta, 70, 598-600. 
[18] McMurry, J. (2000).Organic chemistry. 5th Edition, Brooks/Cole Publishers, Philadelphia.

[19] Freshney, R.I. (1994) Culture of animal cells. 3rd. Edition, Wiley-Liss. USA, 267-308.

[20] Taron, M., Plasencia, C., Abad, A., Martin, C. and Guillot, M. (2000). Cytotoxic effects of topotecan combined with Various Active G2/M-phase anticancer drugs in human tumor-derived cell lines. Invest New Drugs, 18(2), 139-147. (Pubmed Abstract).

[21] Rodrigues, M., Junior, F.B. and Perussi, J.R. (2004) Dipyridamole increases the cytotoxicity of cisplatin in human larynx cancer cells in vitro. brazilian. Journal of Medical Biological Research, 37(4), 591-599.

[22] Toyozumi, Y., Arima, N., Izumaru, S., Kato, S., Morimatsu, M. and Nakashima, T. (2004) Loss of caspase- 8 activation pathway is a possible mechanism for CDDP resistance in human laryngeal squamous cell carcinoma, HEp-2 cells. International Journal of Oncology, 25(3), 721-728. (Pubmed Abstract).

[23] Singh, S., Chhipa, R.R., Vijayakumar, M.V. and Bhat, M.K. (2005) DNA damaging drugs-induced downregulation of $\mathrm{Bcl}-2$ is essential for induction of apoptosis in high-risk HPV-positive HEp-2 and KB cells. Cancer Letters, 236(2), 213-221. (Article in Press).

[24] McAllister, R.M., Melnyk, J., Finklestein, J.Z., Adams, E.C. and Gardner, M.B. (1969) Cultivation in vitro of cells derived from a human rhabdomyosarco- ma. Cancer, 24(3), 520-526.

[25] Al-Shamery, A.M.H. (2003) The study of newcastle disease virus effect in the treatment of transplanted tumors in mice. Master Of Veterinary Medicine, College of Veterinary Medicine, University of Baghdad, Baghdad, Iraq.

[26] Reiners, J.J. and Russell, E.C. (1999) Aryl hy- drocarbon receptor regulation of ceramide-induced apoptosis in murine hepatoma 1c1c7 cells. Journal of Biological Chemistry, 274(4), 2502-2510.

[27] Mahony, D.E., Gilliat, E., Dawson, S., Stockdale, E. and Lee, S.H. (1989) Vero cell assay for rapid detection of clostridium perfringens enterotoxin. Applied and Environmental Microbiology, 55(9), 2141-2143.

[28] Chiang, W., Chang, M.Y. and Lin, C.C. (2003) In vitro cytotoxic antiviral and immunomodulatory effects of Plantago major and Plantago asiatica. American Journal of Chinese Medicine, 31(2), 225-234.

[29] Hannun, Y.A. (1996) Functions of ceramide in coordinating cellular responses to stress, Science, 274(5294), 1855-1859

[30] Michihiko, M., Zhexiong, J., Shohei, Y., Ryuichi, A., Shirou, F., Satoshi, B., Sato, T.K., Naochika, D., Tsuneyo, M., Eda, T.B., Toshiro, O. and Hisanori, U. (2005) Role of membrane sphingomyelin and ceramide in platform formation for Fas-mediated apoptosis. Journal of Experimental Medicine, 202(2), 249-259.

[31] Takeda, S.; Susumu, M.; Kiyomi, T. and Yasuyuki, I. (2006). Apoptosis Occurs via the ceramide recycling pathway in human HaCaT keratinocytes. The Journal of Biochemistry, 139(2), 255-262.

[32] Seumois, G., Marianne, F., Laurent, G., Céline, F., Christophe, D., Cédric, F., Benjamin, D., Cécile, O., Alain, V., Pierre, L. and Fabrice, B. (2007) De novo $\mathrm{C}_{16^{-}}$and $\mathrm{C}_{24^{-}}$-ceramide generation contributes to spontaneous neutrophil apoptosis. The Journal of Leukocyte Biology, 81(6), 1477-1486.

[33] Sugiura, M., Kono, K., Liu, H., Shimizugawa, T., Minekura, H., Spiegel, S. and Kohama, T. (2002) Ceramide Kinase, a Novel Lipid Kinase. The Journal of Biological Chemistry, 277(26), 23294-23300.

[34] Boudker, O. and Futerman, A.H. (1993) Detection and characterization of ceramide-1-phosphate phosphatase activity in rat liver plasma membrane. The Journal of Biological Chemistry, 268(29), 22150-22155.

[35] Rile, G.Y., Yatomi, T.T. and Ozaki, Y. (2003). Ceramide 1-phosphate formation in neutrophils. Acta Haematological, 109, 76-83. 